\title{
Characterization of an Alsodes pehuenche breeding site in the Andes of central Chile
}

\author{
Alejandro Piñeiro ${ }^{1}$, Pablo Fibla², Carlos López ${ }^{3}$, Nelson Velásquez $^{3}$, Luis Pastenes ${ }^{1}$ \\ 1 Laboratorio de Genética y Adaptación a Ambientes Extremos, Departamento de Biología y Química, Facultad de Ciencias Básicas, \\ Universidad Católica del Maule. Av. San Miguel \#3605, Talca, Chile \\ 2 Laboratorio de Genética y Evolución, Departamento de Ciencias Ecológicas, Facultad de Ciencias, Universidad de Chile. Las Palmeras \\ \#3425, Santiago, Chile \\ 3 Laboratorio de Comunicación Animal, Departamento de Biología y Quimica, Facultad de Ciencias Básicas, Universidad Católica del Maule, \\ Av. San Miguel \#3605, Talca, Chile \\ http://zoobank.org/E7A8C1A6-31EF-4D99-9923-FAD60AE1B777 \\ Corresponding author: Luis Pastenes (lpastenes@ucm.cl)
}

Academic editor: Günter Gollmann • Received 10 December 2019 • Accepted 21 March 2020 • Published 7 April 2020

\begin{abstract}
Alsodes pehuenche, an endemic anuran that inhabits the Andes of Argentina and Chile, is considered "Critically Endangered" due to its restricted geographical distribution and multiple potential threats that affect it. This study is about the natural history of $A$. pehuenche and the physicochemical characteristics of a breeding site located in the Maule mountain range of central Chile. Moreover, the finding of its clutches in Chilean territory is reported here for the first time. Finally, a description of the number and morphology of these eggs is provided.
\end{abstract}

\section{Key Words}

Alsodidae, Andean, Anura, endemism, highland wetland, threatened species

The Andean border crossing "Paso Internacional Pehuenche" (38 $59^{\prime} \mathrm{S}, 70^{\circ} 23^{\prime} \mathrm{W}, 2553 \mathrm{~m}$ a.s.1.) is a bioceanic corridor that connects the Región del Maule (Chile) with the Provincia de Mendoza (Argentina). This route stands out as a high mountain landscape, with a Mediterranean continental pluvistational climate that is characterized by snow-type precipitation, which allows the accumulation of water reserves between April and December (Becerra and De Rurange 2018). Likewise, this geographical area is characterized by strong permanent winds, whose intensity varies due to the steep slopes of the mountainsides and the abundant rocky outcrops (Ruiz 2010). The spring thaw waters and the environmental characteristics make up an ecosystem known as highland wetland (i.e., highland drainage basin), where the predominant plant species belong to the Apiaceae family. A high density of branches and leaves characterizes these plants, with short internodes and long roots arranged in the form of cushions, hence the name "cushion plants" (Badano et al. 2002; Arroyo et al. 2003; Badano 2006). This type of vegetation could be of importance for different biological aspects in anurans that inhabit the Andean wetlands. For example, Alsodes pehuenche adult specimens use the underground cavities (tunnels) formed in these vegetative patches to hide during sunny hours (Correa et al. 2013; Herrera and Velásquez 2016a), but may also host reproductive encounters since clutches adhered to the walls of these tunnels have been reported (Corbalán et al. 2014). On the other hand, these Andean wetlands are temporary water ecosystems fed by streams that originate from the slow snowmelt during the summer, since in winter they can be filled up with up to four meters of snow (Corbalán et al. 2010). In summer, the temperatures of these streams can reach $19^{\circ} \mathrm{C}$ at noon (Corbalán et al. 2010), while the air temperature for the 
warmest month (January) can reach $21.5^{\circ} \mathrm{C}$ (Corbalán et al. 2014). In addition, nighttime stream and air temperatures (February) of $6.2{ }^{\circ} \mathrm{C}$ and $5.5^{\circ} \mathrm{C}$, respectively, have been reported (Herrera and Velásquez 2016a). In autumn, water temperatures of $-0.5^{\circ} \mathrm{C}$ have been recorded (Corbalán et al. 2010), while in winter, there have been air temperature recordings of $-6.2{ }^{\circ} \mathrm{C}$ during the coldest month (August) (Corbalán et al. 2014).

Alsodes pehuenche Cei, 1976 (Anura, Alsodidae) is a species that inhabits the Andean wetlands of Argentina and Chile, which shows a very narrow geographical distribution range and a very high level of endemism (Corbalán et al. 2008, 2014; Correa et al. 2013, 2018). Furthermore, it is categorized as "Critically Endangered" (CR) according to the criteria of IUCN SSC Amphibian Specialist Group (2019), since this anuran and its habitat are faced with multiple threats, such as: the paving of the CH-115 international highway, the contaminant particulate material of vehicles, and the impact of domestic livestock trampling, domestic tourism waste and the change in hydrological cycles resulting from climate change (Corbalán et al. 2010; Correa et al. 2013; Lobos et al. 2018); the use of salts to snowmelt during the winter (Corbalán et al. 2014); and the confirmed presence of the chytrid fungus $(\mathrm{Bd})$ in frogs caught in Chilean streams, adjacent to the localities of the border crossing "Paso Internacional Pehuenche", Laguna del Maule and Lo Aguirre (Dayana Vásquez pers. comm., unpublished data).

At present, few studies have delved deeply into the biology and natural history of $A$. pehuenche. Notwithstanding, these have allowed the revelation of some interesting features about this amphibian, such as the following: its complete larval development can take at least four years (Corbalán et al. 2014); adult specimens can inhabit galleries submerged in streams or in wet caves formed on waterfall walls up to one meter tall, which they access by climbing (Herrera and Velásquez 2016a); in addition, this anuran shows a notorious sexual dimorphism in adult stages (Cei 1965, 1976; Cei and Roig 1965; Herrera and Velásquez 2016b). However, our knowledge concerning this species is still limited.

In order to advance our knowledge of this species, we monitored a specific breeding site $(250 \times 70$ meter transect, approximately) of $A$. pehuenche located on the south side of the CH-115 Chilean international route in the Provincia de Talca, Región del Maule (3559'56.1"S, $70^{\circ} 24^{\prime} 12.3^{\prime \prime}$; Fig. 1). This area was visited during the reproductive period of A. pehuenche (December 2016, January, March, May and December 2017 and January 2018), since during these months, access to the study site (i.e., open border crossing) is always ensured (Cei and Videla 2003). Several physicochemical parameters of air and water were recorded in one of the Andean wetland streams ("monitoring site"; Fig. 2A), during each of the field expeditions (e.g., once per month). We recorded water temperature, $\mathrm{pH}$, electrical conductivity, salinity and total dissolved solids (Multi-Parameter Testr35, Oakton Instruments), along with air temperature and relative humidity (Precision Psychrometer RH390, Extech Instruments). All measurements were conducted between 1:00 p.m. and 2:00 p.m., recording a single value (no replicate) for each of them. In addition, a search for adult specimens and/or clutches was carried out on each of the field expeditions. Aquifer chambers under the vegetation and the ventral face of submerged flat stones in streams were investigated along the transect area (Fig. 1). The clutches found were photographed for their registration and the number of eggs for each of the clutches was estimated in situ.

During our monitoring, we observed that the different streams that feed the study site are of the lotic and smooth flow type, as Becerra and De Rurange (2018) had already reported. Table 1 shows all recorded values for the measured physicochemical parameters on each of the monitoring dates, as well as their average values (mean \pm standard error). Likewise, we observed $A$. pehuenche larvae in different larval developmental stages (i.e., pre-metamorphic and metamorphic stages), occupying the widest and deepest areas of these streams. In addition, A. pehuenche adult specimens (males and females) were observed on every field expedition to the monitoring site. However, only five clutches (separated from each other by approximately 30-40 meters) were found exclusively on the field expedition carried out on December 21, 2017. During that year, the Pehuenche border crossing was reopened on November $1^{\text {st }}$, but by then there was still snow on both sides of the CH-115 international route, since it began to melt only in mid-November (Jaime Campos pers. comm., Pehuenche Border Complex Administrator, Chile).

All clutches registered in this study had a compact cluster shape and were found adhered to the underside of the vegetative substrate (Fig. 2B) or flat stones (Fig. $2 \mathrm{C}$ ), but in both cases, semi-submerged in the water and protected from the sun. In order to photograph the clutches, part of the vegetative substrate was removed and the flat stones were turned over since the clutches were always found adhered to the underside of the substrate and protected from the sun. Sectors of the stream where the clutches were found were less than $60 \mathrm{~cm}$, both deep and wide. In addition, A. pehuenche larvae in different developmental stages were found in other sectors of the stream. However, no recently hatched larvae were found on the January 2018 expedition. Eggs were spherical and each delimited by its own translucent vitelli. In addition, the embryos were whitish in color (Fig. 2D) and were close to the hatching event (i.e., at developmental stages 18 and 19, Gosner 1960). The number of eggs from only two selected clutches was counted, resulting in approximately 500 and 200 units (Fig. 2B, C), respectively. The presence of a single $A$. pehuenche adult male specimen was observed in each of the clutches found (Fig. 2C).

As far as we know, there are only two published studies on this species, where environmental parameters were analyzed at a breeding site located on the eastern slopes of the Argentinean Andes (Corbalán et al. 2008, 2010); 


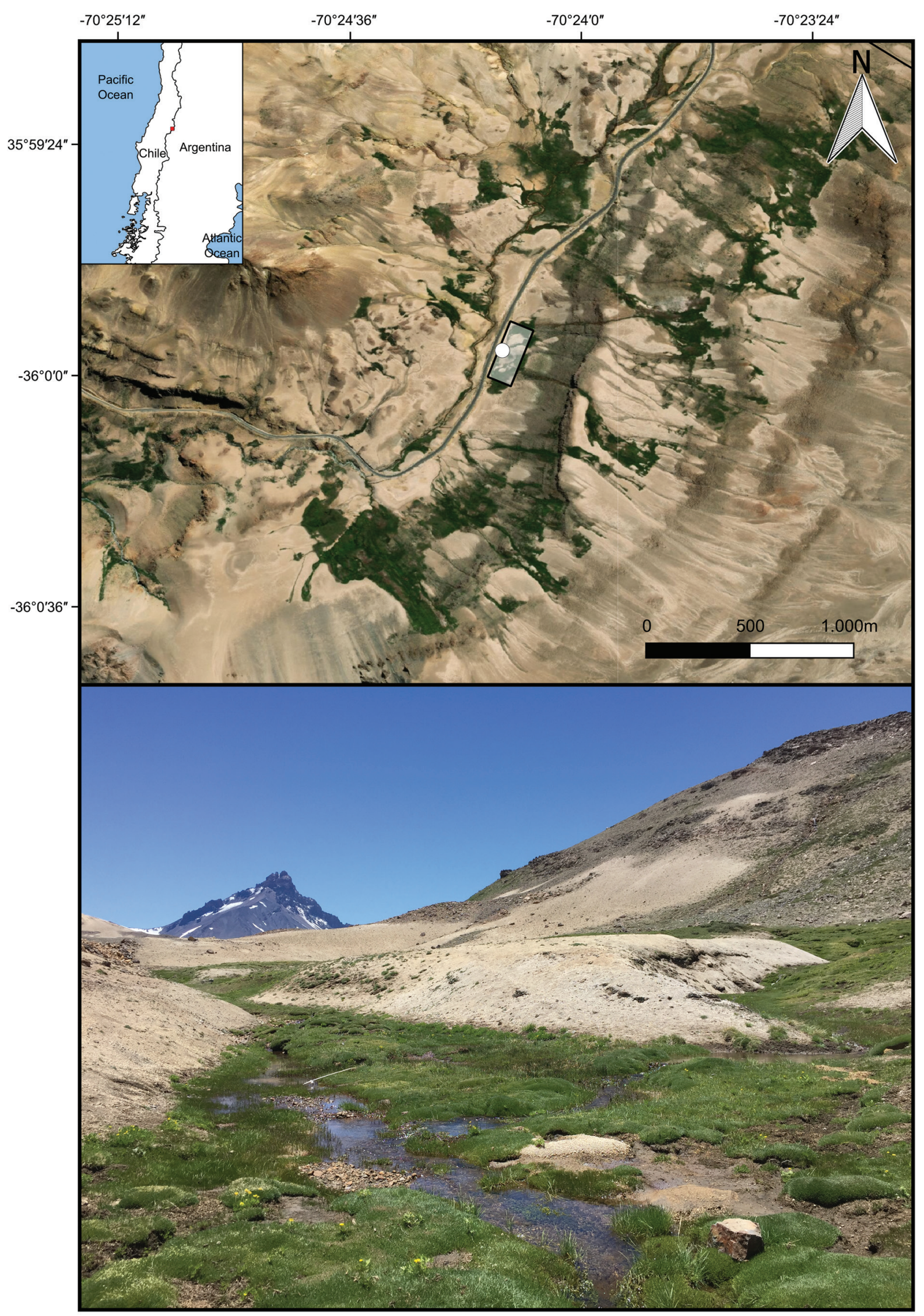

Figure 1. Geographical location of the study site in the Andes mountain range (small red square on the map; $35^{\circ} 59^{\prime} 56.1^{\prime \prime} \mathrm{S}$, $70^{\circ} 24^{\prime} 12.3^{\prime \prime} \mathrm{W}$ ) and panoramic view of the monitoring site inhabited by Alsodes pehuenche. This habitat corresponds to a system of Andean wetlands, with streams of varied flow and vegetative patches in which the Mulinum spinosum ("neneo") plant predominates. The ESRI satellite image shows the georeferenced study site (white circle) and the monitored transect area (rectangle). 
Table 1. Recording of the air and water physicochemical parameters of an Andean stream inhabited by Alsodes pehuenche in central Chile. Date $=$ month $/$ day/year; Average values $=$ mean \pm standard error; $\mathrm{T}=$ temperature; $\mathrm{RH}=$ relative humidity; $\mathrm{TDS}=$ total dissolved solids; $\mu \mathrm{S}=$ micro-Siemens; ppm = parts per million.

\begin{tabular}{lccccccc}
\hline \multirow{2}{*}{ Date } & \multicolumn{2}{c}{ Air } & \multicolumn{5}{c}{ Water } \\
\cline { 2 - 8 } & $\mathbf{T}_{\text {air }}\left({ }^{\circ} \mathbf{C}\right)$ & $\mathbf{\% ~ R H}$ & $\left.\mathbf{T}_{\text {water }}{ }^{\circ} \mathbf{C}\right)$ & $\mathbf{p H}$ & Conductivity $(\boldsymbol{\mu S})$ & $\mathbf{T D S}(\mathbf{p p m})$ & Salinity (ppm) \\
\hline $22 / 12 / 16$ & 19.6 & 32.4 & 20.7 & 7.83 & 34.2 & 21.2 & 14.7 \\
$24 / 01 / 17$ & 21.5 & 33.3 & 22.6 & 7.74 & 49.8 & 35.5 & 20.4 \\
$15 / 03 / 17$ & 16.5 & 36.8 & 12.1 & 7.76 & 34.5 & 24.5 & 20.9 \\
$04 / 05 / 17$ & 13.3 & 29.3 & 5.6 & 9.26 & 41.7 & 29.6 & 20.4 \\
$21 / 12 / 17$ & 20.1 & 24.8 & 18.6 & 7.54 & 32.6 & 23.0 & 19.6 \\
$18 / 01 / 18$ & 19.3 & 20.4 & 19.4 & 7.23 & 40.2 & 28.6 & 24.2 \\
Average values & $18.4 \pm 1.22$ & $29.5 \pm 0.02$ & $16.5 \pm 2.62$ & $7.9 \pm 0.29$ & $38.2 \pm 2.64$ & $27.1 \pm 2.14$ & $20.0 \pm 1.25$ \\
\hline
\end{tabular}

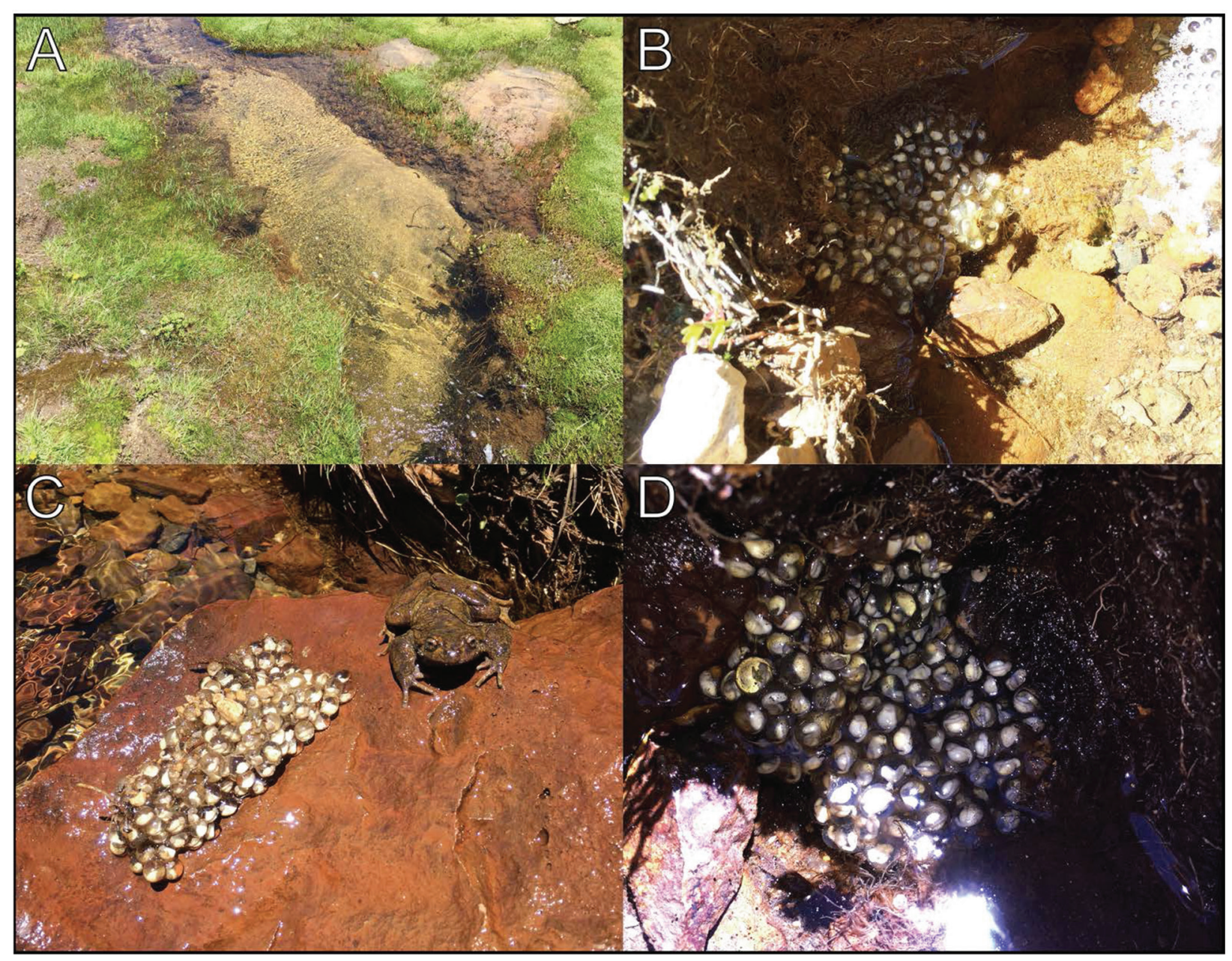

Figure 2. A) Detail of the stream monitored at the study site. B) An Alsodes pehuenche clutch adhered to the vegetative substrate. C) Another clutch adhered to the ventral face of a flat stone (the stone was turned over to take the photograph). Both clutches were in direct contact with the flow of the Andean wetland streams. In addition, an A. pehuenche adult male specimen, who was found next to this clutch, is shown. D) Detail of one of the clutches found is shown.

however, only two of the parameters reported are comparable to our study. The characterization of the Argentinean streams showed $\mathrm{pH}$ values ranging from 6.08 to 7.66 and temperatures of up to $19{ }^{\circ} \mathrm{C}$ at noon. In the current study, the measurement of the Chilean stream parameters showed a low dispersion for the recorded data during the summer months (December to March), with average values of water $\mathrm{pH}$ and temperature of $7.6 \pm 0.11$ and $18.7 \pm$ $1.78{ }^{\circ} \mathrm{C}$, respectively. These values were similar to those reported by Corbalán et al. (2010). However, in our study the water temperature decreased to $5.6^{\circ} \mathrm{C}$ and the $\mathrm{pH}$ increased dramatically to a value of 9.26 during May 2017 
(autumn). Such decrease in temperature and increase in $\mathrm{pH}$ may be linked to the snowfall that occurred weeks before the measurement. It has been documented that the increase in $\mathrm{pH}$ could be related to salt leaching in the soil due to precipitations (Henao and Bernal 2011). Furthermore, traffic road sediments (rich in elements such as $\mathrm{Pb}$, $\mathrm{Cu}$, Mo, among others) could be deposited in the Andean wetlands; therefore, this may alter the chemical properties of stream water (Corbalán et al. 2010).

On the other hand, A. pehuenche egg clutches are very difficult to find and have only been reported twice (by Corbalán et al. 2014 and in this study). In our case, the finding of clutches in early summer could indicate that adults of this species begin their reproductive season precisely at the end of November or beginning of December, just when the snow is about to melt completely. Corbalán et al. (2014) estimated a number of eggs per clutch probably close to 100 units, which is a lower value than that reported in our study. This could be because the aforementioned authors did not find clutches as such, but rather found a gravid female who released her eggs spontaneously during its manipulation. Regardless of those results, our recording of the number of eggs per clutch is within the range of other related species, such as Eupsophus emiliopugini (Úbeda and Núñez 2006). Moreover, the presence of a single $A$. pehuenche adult male specimen in each of the clutches found could suggest the existence of a reproductive strategy associated to the parental care, a mechanism which has been reported in other anurans present in Chile, such as the case of the Eupsophus, Batrachyla and Rhinoderma genera (Soto et al. 2008). For example, Úbeda and Núñez (2006) have reported that Eupsophus calcaratus, E. emiliopugini and E. nahuelbutensis adults remain for prolonged periods of time near the fertilized eggs, a fact that is associated with a marked decrease in the body mass of these anurans. However, we need more evidence to confirm our assumption.

In conclusion, our study shows that the environmental characteristics evaluated at the monitored breeding site are similar to those reported in the populations of $A$. pehuenche that inhabit Argentinean territory. In addition, this study reveals the discovery of clutches of $A$. pehuenche in Chilean territory. However, our observations showed differences in the characterization of the number of eggs per clutch. The presence of males at the clutch sites opens up the possibility of a parental care behavior in this species.

\section{Acknowledgements}

We are grateful to Isabel Lobos, Javier Rivas and Florencia A. Velásquez for participating in the field expeditions. Luis Pastenes thanks the FONDECYT 3140483 project. This study was carried out during the execution of the FONDECYT 11140752 project allocated to Nelson Velásquez.

\section{References}

Arroyo MTK, Cavieres LA, Peñaloza A, Arroyo-Kalin MA (2003) Positive interactions between the cushion plant Azorella monantha (Apiaceae) and alpine plant species in the Chilean Patagonian Andes. Plant Ecology 169: 121-129. https://doi.org/10.1023/A:1026281405115

Badano EI, Molina-Montenegro MA, Quiroz CL, Cavieres LA (2002) Efectos de la planta en cojín Oreopolus glacialis (Rubiaceae) sobre la riqueza y diversidad de especies en una comunidad alto-andina de Chile central. Revista Chilena de Historia Natural 75(4): 757-765. https://doi.org/10.4067/S0716-078X2002000400011

Badano E (2006) Asociaciones de especies a plantas en cojín: sus consecuencias sobre la diversidad de especies vegetales en comunidades altoandinas. Ecosistemas 15(1): 109-112. http://rua.ua.es/dspace/ handle/10045/7867

Becerra C, De Rurange J (2018) Modelo de susceptibilidad a procesos de remociones en masa en rutas cordilleranas de Chile Central: Ruta 115 $\mathrm{CH}$, Paso Pehuenche, Región del Maule. Investigaciones Geográficas 55: 89-110. https://doi.org/10.5354/0719-5370.2018.50799

Cei JM (1965) Comentarios sobre el hallazgo de Telmatobius montanus Lataste (in Philippi) en la cordillera al sur de Mendoza. Publicación ocasional del Instituto de Biología de la Universidad Nacional de Cuyo 7: 1-4.http://sedici.unlp.edu.ar/bitstream/handle/10915/85438/ Documento_completo.pdf?sequence=1\&isAllowed=y

Cei JM, Roig VG (1965) The systematic status and biology of Telmatobius montanus Lataste (Amphibia, Leptodactylidae). Copeia 1965(4): 421-425. https://doi.org/10.2307/1440989

Cei JM (1976) Remarks on some Neotropical amphibians of the genus Alsodes from Southern Argentina. Atti della Società Italiana di Scienze Naturali e del Museo Civico di Storia Naturale di Milano 117: 159-164. https://ia601007.us.archive.org/31/items/attidellasocieti1171 unse/attidellasocieti1171unse.pdf

Cei JM, Videla F (2003) A new species of Liolaemus lacking precloacal pores in males from the Andean south-eastern mountains of Mendoza Province, Argentina. (Liolaemidae, Iguania, Lacertilia, Reptilia). Bollettino Museo Regionale di Scienze Naturali Torino 20 (2): 275-290. http://sedici.unlp.edu.ar/bitstream/handle/10915/85661/ Documento_completo.pdf? sequence $=1 \&$ is Allowed $=\mathrm{y}$

Corbalán V, Debandi G, Úbeda C (2008) Alsodes pehuenche. Larval biology. Herpetological Review 39: 457-458. https://ri.conicet.gov. ar/handle/11336/93000

Corbalán V, Debandi G, Martínez F (2010) Alsodes pehuenche (Anura: Cycloramphidae): past, present and future. Cuadernos de Herpetología 24(1): 17-23. https://www.researchgate.net/publication/258223561_Alsodes_pehuenche_Anura_Cycloramphidae Past_present_and_future

Corbalán V, Debandi G, Martínez F, Úbeda C (2014) Prolonged larval development in the Critically Endangered Pehuenche's frog Alsodes pehuenche: implications for conservation. Amphibia-Reptilia 35(3): 283-292. https://doi.org/10.1163/15685381-00002951

Correa C, Pastenes L, Iturra P, Calderón P, Vásquez D, Lam N, Salinas H, Méndez M (2013) Confirmation of the presence of Alsodes pehuenche Cei, 1976 (Anura, Alsodidae) in Chile: morphological, chromosomal and molecular evidence. Gayana 77(2): 125-131. https:// doi.org/10.4067/S0717-65382013000200006

Correa C, Zepeda P, Lagos N, Salinas H, Palma RE, Vásquez D (2018) New populations of two threatened species of Alsodes (Anura, A1sodidae) reveal the scarce biogeographic knowledge of the genus 
in the Andes of central Chile. Zoosystematics and Evolution 94(2): 349-358. https://doi.org/10.3897/zse.94.25189

Gosner K (1960) A simplified table for staging anuran embryos and larvae with notes on identification. Herpetologica 16(3): 183-190. https://www.jstor.org/stable/3890061

Henao L, Bernal M (2011) Tolerancia al pH en embriones y renacuajos de cuatro especies de anuros colombianos. Revista de la Academia colombiana de Ciencias Exactas, Físicas y Naturales 35(134): 105-110. http://www.scielo.org.co/scielo.php?script=sci_arttext\&pid=S0370-39082011000100010

Herrera F, Velásquez NA (2016a) Uso de cuevas en Alsodes pehuenche Cei 1976 (Amphibia, Anura, Alsodidae). Boletín Chileno de Herpetología 3: 17-20. http://www.boletindeherpetologia.com/uploads/3/2/2/9/32291217/5._herrera_velasquez2016b2.pdf

Herrera F, Velásquez NA (2016b) Dimorfismo sexual en Alsodes pehuenche Cei 1976 (Amphibia, Anura, Alsodidae). Boletín Chileno de Herpetología 3: 4-6. http://www.boletindeherpetologia.com/uploads/3/2/2/9/32291217/2. herrera_velasquez2016.pdf

IUCN SSC Amphibian Specialist Group (2019) Alsodes pehuenche. The IUCN Red List of Threatened Species 2019: e. T56319A79811367. https://doi.org/10.2305/IUCN.UK.2019-1. RLTS.T56319A79811367.en
Lobos G, Vidal-Maldonado MA, Correa-Quezada CL, Labra-Lillo A, Díaz-Páez H, Charrier A, Rabanal FE, Díaz S, Tala C (2013) Anfibios de Chile, Un Desafío para la Conservación. Santiago de Chile: Ministerio del Medio Ambiente, Fundación Facultad de Ciencias Veterinarias y Pecuarias de la Universidad de Chile y Red Chilena de Herpetología. https://mma.gob.cl/wp-content/uploads/2018/08/ Conservacion-de-Anfibios.pdf

Ruiz Silva C (2010) Propuesta de planificación ecológica para el sector Laguna del Maule y el corredor Pehuenche en relación a la ruta Internacional 115-CH, comuna de San Clemente, Región del Maule. http://repositorio.uchile.cl/handle/2250/100298

Soto E, Sallaberry M, Núñez J, Méndez M (2008) Desarrollo larvario y estrategias reproductivas en anfibios. In: Vidal MA, Labra A (Eds) Herpetología de Chile. Science Verlag, Santiago, 333-357. https:// www.researchgate.net/publication/269404306_Desarrollo_larvario_y_estrategias_reproductivas_en_anfibios

Úbeda CA, Núñez JJ (2006) New parental care behaviours in two telmatobiine genera from temperate Patagonian forests: Batrachyla and Eupsophus (Anura: Leptodactylidae). Amphibia-Reptilia 27(3): 441-444. https://doi.org/10.1163/156853806778190015 